\title{
Tax Dispute Analysis of Surface Water Tax (Review Decision Number 2791/B/PK/PJK/2019)
}

\author{
Intan Puspanita ${ }^{1 *}$, Asih Machfuzhoh², Mulyanah ${ }^{3}$ \\ ${ }^{*}, 2,3$ University of Sultan Ageng Tirtayasa, Serang, Indonesia \\ Corresponding Author: intan.puspanita@untirta.ac.id ${ }^{1 *}$
}

Keywords : contract of work, juridical review, surface water tax.

\begin{abstract}
:
The surface water tax creates different perceptions due to differences in the imposition of taxes regulated in regional regulations and contracts of work, one of which contains tax provisions that apply specifically. This study discusses a review of the arguments for the Judicial Review Decision Number 2791/B/PK/PJK/2019). This study uses literature research methods. The results of this study concluded that the panel of judges granted the appeal applicant on the basis that the Papuan provincial government could not collect surface water tax because it was not in accordance with article $32 \mathrm{~A}$ and article $33 \mathrm{~A}$ of the income tax law and the contents of the contract of work.
\end{abstract}




\section{Introduction}

Since Indonesia entered the era of regional autonomy as stipulated in Law number 33 of 2004 in conjunction with Law no. 23 of 2014 concerning local government, it requires local governments to have independence and responsibility to provide services to the community and development in their regions. The aim is to accelerate the realization of community welfare, empowerment, and community participation. Local governments have the responsibility to improve people's living standards, especially for community services such as entertainment venues, restaurants, health, security, education, transportation, and others. The existence of this requires local governments to explore as much as possible their sources of income independently in order to carry out these responsibilities. Law Number 33 of 2004 concerning the financial balance between the central government and regional governments stipulates that regional revenues in the implementation of decentralization consist of regional taxes and regional levies as a source of regional original income (PAD) originating from the region itself and can be developed under conditions of each area.

Taxes are defined as people's contributions to the treasury of a country which are based on law so that they can be forced, without receiving direct remuneration. In Law No. 28 of 2009 Article 2 paragraph 1 explains that regional taxes and regional levies are several types of taxes levied by local governments. The Surface Water Tax is one of the Provincial Taxes which is a source of funds for the provincial government. Surface water tax is a tax given to taxpayers because they have taken and utilized surface water. Surface water is all water found on the land surface, excluding sea water both in the sea and on land. One of the benefits that the state can provide to individuals or legal entities is the utilization or extraction of surface water. The provision of this benefit may be subject to a forced surface water tax by the government and the beneficiary is obliged to pay taxes in accordance with statutory regulations. The Head of the Regional Tax Management Agency of Papua Province, Gerson in tirto.id (2017) said that until 2017 motor vehicle taxes, surface water and regional levies remained the main priority of tax revenue in Papua Province.

Mining work contract with PT. Freeport is one of the Contracts of Work that is very detrimental to Indonesia (Abidin, 2011). The term contract of work is a contract made by and between the Government of the Republic of Indonesia and a foreign investment company (Ministry of Mining and Energy Decree, 1996). The surface water tax is a regional tax that is classified as a provincial tax with arrangements in accordance with regional regulations, but with the existence of a contract of work, one of which contains tax provisions that apply specifically different from the provisions in regional regulations, it will lead to different perceptions which lead to problems in collecting it (Kotan, 2020). This case happened to PT Freeport Indonesia. The background of the regulation of the contract of work system at the beginning of the mining policy in 1967 was the government's effort to bring in capital to carry out development through the 
mining sector by providing contracts of work for business actors who wish to carry out mining business activities in Indonesia (Lathif, 2017).

The discussion in this study is centered on the "surface water tax" based on the Supreme Court of the Republic of Indonesia Decision Number 2791/B/PK/PJK/2019 on the application for judicial review of the Tax Court Decision Number Put. 113371.06/2016/PP/M.IIIB Year 2018, October 30, 2018, for examination of the Regional Tax Assessment-Surface Water Tax 973/1501. In the decision of the Tax Court Number PUT-113371.06/2016/PP/M.IIIB of 2018 partially granted the appeal of the Appellant to the Decree of the Governor of Papua Number 188.4/445/the Year 2016, dated December 28, 2016, regarding the rejection of the submission of an objection to the Regional Tax Assessment Letter Surface Water Tax where taxpayers must pay a surface water tax of Rp. 21,764,102,544.00. PT X as a taxpayer then submitted a judicial review of the Tax Court's decision to the Supreme Court, and the results of the judicial review submitted by the petitioner for judicial review were granted in other words, the decision of the Supreme Court in favor of PT $X$ so that the Tax Court's Decision Number PUT-113371.06/2016 /PP/M.IIIB Year 2018 canceled.

Based on the explanation above and the curiosity about why local governments were defeated based on the Supreme Court's decision, this study was conducted to analyze the arguments used in the trial, so this research is entitled: Analysis of Tax Disputes on Surface Water Tax (Review Decision Number 2791 /B/PK/PJK/2019).

\section{Research Method}

This study uses a qualitative approach. The qualitative approach does not aim to confirm reality, as in hypothesis testing, but instead reveals (or builds) a reality that was previously tacit, implicit, hidden, becomes real, explicit or visible (Irawan, 2006). This research uses a qualitative approach to literature study by looking at the sources of books, documents, national and international journals, as well as laws related to the research topic. The journals investigated were related to surface water tax and analysis related to the Judicial Review Decision Number 2791/B/PK/PJK/2019.

The limitation of this research is that this research only uses literature/library research method, that is, research is only based on literature in the form of books, documents, national and international journals, as well as laws related to the research topic. This research is only based on the matters disclosed in the Judicial Review Decision Number 2791/B/PK/PJK/2019 which was downloaded from the Supreme Court website, without looking at the research paperwork conducted by the Supreme Court judges.

\section{Result and Discussion}

This case stems from a claim for a Regional Tax Assessment Letter (SKPD) for surface water tax from the Papua provincial government for the August 2016 tax period related to a bill of Rp21,764,102,544.00. The Government of Papua Province collects Surface Water Tax based 
on Regional Regulation No. 4 of 2011. Based on regional regulation No. 4 of 2011 on the extraction and/or utilization of surface water carried out by individual taxpayers or legal entities is subject to surface water tax at a rate of $10 \%$ based on tax imposition, in this case, namely the acquisition value of water. In article 34 paragraph (2) Regional Regulation no. 4 of 2011 the acquisition value of surface water takes into account the following factors: type of water source, location of water source, the purpose of water extraction and/or utilization, volume of water taken and/or utilized, water quality, area where water is taken and/or utilized. and the level of environmental damage caused by the extraction and/or utilization of water. In the case of the imposition of a surface water tax, the surface water taxpayer is obliged to report to the governor or appointed official on the calculation and payment of the surface water tax owed within a certain period of time, for example, twenty days from the end of the tax period, filled using SPTPD with clear, correct, complete and signed.

In Decision Number: 113371.06/2016/PP/M.IIIB of 2018 the appellant in this case the Papuan Provincial government stated that because the Contract of Work is subject to the law of freedom of contract as regulated in the Civil Code, while the Establishment of Laws and Regional Regulations Provinces are subject to the guidelines regulated in Law Number 12 of 2011 concerning the Formation of Legislation. In the 2018 appeal decision, the arguments according to the Papua Provincial Government regarding the contract of work are as follows:

1. The Contract of Work is a civil law product while the PDRD Law is a public law product, so the Contract of Work only binds the parties who make it while the Law and Provincial Regulations bind all citizens, including civil legal entities, so it can be concluded that the Contract of Work not domiciled as lex specialist with respect to the Law or Regional Regulation of the Regional Tax Province.

2. The validity period of the Contract of Work is based on the agreement of the parties as stipulated in the Contract of Work, while the Law or Provincial Regulation is valid as long as it has not been revoked by a higher or equivalent level regulation or based on a court decision;

3. The Contract of Work must be understood in the context of tax conveniences at the beginning of mining activities while the Appellant has been operating in Papua for more than 35 years so that the application of the article is no longer relevant, in addition to the laws and regulations that form the legal basis for the birth of the Contract. The work itself, namely Law Number 11 of 1967 concerning Principles of Mining has been revoked and replaced by Law Number 4 of 2009 concerning Minerals and Coal

4. The Contract of Work and the Law on Regional Taxes and Levies are two different legal products, where the Contract of Work is a product of Civil Law while the PDRD Law is a product of Public Law. in the types of regulations in the hierarchy of laws and regulations in accordance with Article 7 of Law Number 12 of 2011 concerning the Establishment of Legislation. 
According to Redi (2016) the contract of work of PT Freeport Indonesia is an agreement that is contrary to Pancasila and the 1945 Constitution, but because the contract of work of PT Freeport Indonesia is a contractual agreement that is subject to civil law, the principle of pacta sunt servanda which results in the sanctity of contract is a consideration that the validity of the contract of work must be respected until the expiration of the contract.

Based on the decision of PUT-113371.06/2016/PP/M.IIIB Year 2018, PT FI as the applicant for appeal, several arguments were put forward regarding the contract of work, including the following:

1. The Contract of Work is a valid and legally binding agreement like the law for the parties in this case the Appellant and the Government of the Republic of Indonesia, including the Regional Government, so that the provisions of the Contract of Work including the tax provisions must be complied with and applied by both parties in good faith (Pacta Sunct Servanda)

2. Whereas according to the Appellant regarding the principle of Pacta Sunt Servanda based on the provisions of Article 13 of the Contract of Work, the Appellant is only obliged to pay levies, taxes, charges, and duties imposed by the Regional Government in Indonesia which at the time of the Contract of Work signed (30 December 1991) have been approved by the Central Government. Bearing in mind that on December 30, 1991, the applicable regional tax or regional levy on the use of surface water was local regulation number 5 in 1990, the Appellant is only obliged to pay Regional Tax or Regional Retribution on the use of surface water based on Regional Regulation Number 5 of 1990.

3. whereas according to the Appellant, related to the dispute over the imposition of the Surface Water Tax, the relevant tax provisions used are as set out in Article 13 of the Contract of Work.

4. Provisions on Regional Taxes that can be imposed on the Appellant have been specifically regulated in Article 13 (x) of Jo's Contract of Work. point 10 (ten) of Article 13 of the Contract of Work which clearly stipulates that the Appellant is only obliged to pay Regional Taxes or Regional Levies or other regional levies based on the provisions which at the time the Contract of Work was signed (30 December 1991) were in force (has been approved by the Central Government).

PT FI as an appellant submitted a review to the Supreme Court because based on PUT113371.06/2016/PP/M.IIIB Year 2018 the panel of judges only granted part of the appeal applicant's wish and still had to pay Rp21,764,102,544.00. Article 77 paragraph (3) of the Tax Court Law reads:

"The disputing parties can submit a review of the Tax Court's decision to the Supreme Court"

PT FI wants the panel of judges to cancel the Regional Tax Assessment Letter on the surface water tax so that PT FI does not have the obligation to pay taxes on the surface water 
tax. The argument put forward by the applicant for review, in this case, PT FI, is that the Surface Water Tax can only be imposed in accordance with the applicable provisions in the Contract of Work.

Based on the Judicial Review Decision Number 2791/B/PK/PJK/2019, the judge granted the petition for reconsideration submitted by the petitioner for reconsideration of the surface water tax case that was still to be paid and canceled the Tax Court Decision Number: 113371.06/2016/PP/M IIIB 2018, October 30, 2018. The basis for consideration by the panel of judges are:

1. It is bound by the legal doctrine that the Contract of Work between the Applicant for Review and the Government of the Republic of Indonesia which has been approved by the Government of the Republic of Indonesia after receiving a recommendation from the House of Representatives and related Ministries is binding from the Central Government to the Regional Government, therefore it is also in accordance with a letter from the Minister Finance Number S-1032/MK.04/1988, dated December 15, 1988, is of a special nature, namely Lex specialis derograt lex generalis and applies as a law for its makers (vide 1338 paragraph (1) of the Civil Code).

2. The specific nature of having the same jurisdiction and position of legal treatment without any difference in treatment in legal service.

3. The engagement or agreement must be carried out in good faith (Article 1338 paragraph (3).

4. The tax policy between the Central Government and the Regional Government is essentially a system and part of a national fiscal policy.

5. Article 13 of the Contract of Work expressly stipulates that "The company is not obligated to pay other taxes, duties, levies, donations, charges or fees now or in the future which is levied or imposed or approved by the Government other than those stipulated in this Article and any other provisions of this Agreement" and therefore the Appeal's (now the Respondent for Review) correction in the case cannot be defended.

Thus, according to the panel of judges, the Papua Provincial Government's move to collect surface water tax to Freeport is not in accordance with the provisions of the applicable laws and regulations as stipulated in Article 32A and Article 33A paragraph (4) of the Income Tax Law in conjunction with the Elucidation of Article 13 of the Law. Number 24 Year 2000 concerning International Agreement Article 27 Vienna Convention in conjunction with Article 13 Contract of Work in conjunction with Letter of the Minister of Finance Number S-604/MK.017/1998. Article $32 \mathrm{~A}$ and Article $33 \mathrm{~A}$ paragraph (4) of the Income Tax Law which reads.

Pasal 32A:

"The government is authorized to enter into agreements with the governments of other countries in the context of avoiding double taxation and preventing tax evasion". 
Pasal 33A paragraph (4):

"Taxpayers who run a business in the field of oil and gas mining, general mining, and other mining based on a production sharing contract, contract of work, or mining concession agreement which are still valid at the time this Law comes into effect, the tax is calculated based on the provisions in the contract for the results, contract of work, or mining concession agreement until the end of the said contract or cooperation agreement".

According to the panel of judges, the reasons for the petition for judicial review are quite well-founded and can be justified because the arguments submitted are of the nature of a decisive opinion so that they deserve to be granted because there has been a decision of the Tax Court which clearly contradicts the prevailing laws and regulations as regulated in Article 91 letter e of Law Number 14 of 2002 concerning the Tax Court.

\section{Conclusion}

Based on the discussion above, it can be concluded that there are differences in perception due to differences in taxation as regulated in regional regulations and contracts of work. The judicial review decision made by PT FI is because the Tax Court Decision Number PUT113371.06/2016/PP/M.IIIB of 2018 only partially granted PT FI's wishes so that PT FI submitted a reconsideration. The judicial review decision number 2791/B/PK/PJK/2019 granted PT FI's request based on the panel of judges' considerations, namely that the contract of work agreement applies lex specialis derogate lex generalis or special law (lex specialis) that overrides general law (lex generalis) and applies as law for the maker and in addition to it is also the step of the Papuan provincial government to collect a surface water tax that is not under the income tax law article 32A and 33A paragraph (4) and the contents of the contract of work.

\section{References}

Abidin, RF. (2011). Aspek Yuridis Renegosiasi Kontrak Karya di Indonesia (Studi Kontrak Karya antara Pemerintah Republik Indonesia dengan PT Freeport Indonesia). Jurnal Kajian Hukum Islam dan Sosial Kemasyarakatan, Vol. 11 No.1.

Aritonang, J. (2018). Analisis Sengketa Pajak atas Biaya Seragam (Studi Kasus atas Putusan Peninjauan Kembali Nomor 1710/B/PK/PJK/2016). Simposium Nasional Keuangan Negara.

Kotan, GMJ. (2020). Pemungutan Pajak Air Permukaan terhadap Perusahaan Pertambangan sebagai Pemegang Kontrak Karya dengan Pemerintah. Thesis Universitas Airlangga.

Lathif, N. (2017). Tinjauan Yuridis tentang Kewenangan Pemerintah Provinsi dalam Penerbitan Izin Usaha Pertambangan Batubara. Jurnal Panorama Hukum Vol.2 No.2. 
Handoko, AMA \& Purwaningsih, A. (2014). Analisis Faktor-faktor yang Mempengaruhi Putusan Sidang Pengadilan Pajak Pada Kasus Banding Pajak Pertambahan Nilai. Jurnal Ekonomi Akuntansi hal 1-14.

Irawan, Prasetya. (2006). Penelitian Kualitatif dan Kuantitatif Untuk IImu-ilmu Sosial. Jakarta: Universitas Indonesia Fakultas IImu Sosial dan Politik.

Gubernur Provinsi. (2011). Peraturan Daerah Provinsi Papua No. 4 Tahun 2011 tentang Pajak Daerah.

Redi, A. (2016). Kontrak Karya PT Freeport Indonesia dalam Perspektif Pancasila dan UUD NRI 1945. Jurnal Konstitusi, Vol. 13 No.3.

Republik Indonesia. (2000). Undang-undang Republik Indonesia Nomor 34 tahun 2000 tentang Perubahan Undang-undang Republik Indonesia Nomor 18 tahun 1997 tentang Pajak Daerah dan Retribusi Daerah.

Republik Indonesia. (2002). Undang-undang Nomor 14 tahun 2002 tentang Pengadilan Pajak.

Republik Indonesia. (2008). Undang-Undang Republik Indonesia Nomor 36 Tahun 2008 tentang Pajak Penghasilan.

Republik Indonesia. (2011). Undang-Undang Republik Indonesia Nomor 12 tahun 2011 tentang Pembentukan Peraturan Peraturan Perundang-Undangan.

Ryan, N. (2017). Pemprov Papua Minta Freeport Lunasi Pajak Air Permukaan. https://tirto.id/pemprov-papua-minta-freeport-lunasi-pajak-air-permukaan-cxmN. 
